\title{
Samtaler om ligestilling \\ - indenfor, udenfor, udenom, og ind i diskursen
}

\section{Af Harriet Bjerrum Nielsen}

Det store forskningsprojekt "Konsbarviever $i$ de højere uddannelser og forskningen" har på fornem vis bragt Danmark i front, nair det galder forskning og analyse af sporgsmålet om køn $i$ akademia. Men bvordan kan resultaterne oversattes til forskningsstrategisk praksis? Hvordan kan forandring overhovedet forstais? Har det danske konsforskningsmiljø over de sidste 25 àr veret praget af teoripolitisk korvektbed, som har hindret effektiv institutionalisering?

\section{ESSAY}

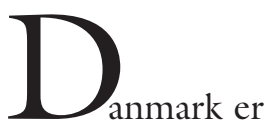

som bekendt dårligst $\mathrm{i}$ den nordiske klasse når det gælder ligestilling $\mathrm{i}$ forskning $\mathrm{og}$ højere uddannelse. De norske tal er måske ikke så voldsomt meget højere, ${ }^{1}$ men det politiske klima for ligestillingskrav er anderledes. I modsætning til sine danske søstre fulgte de norske kvindeforskere i 1970- og 80erne (ligesom de kvindelige politikere for øvrigt) en pragmatisk institutionaliseringsstrategi som gradvis bragte flere kvinder ind i faste stillinger og som givetvis også har medvirket til at styrke ligestilling som politisk legitimt projekt i akademia. Dertil kommer andre kulturelle forskelle som at man i Norge i højere grad godtager politik 'fra oven' på en del områder som i Danmark opfattes som tilhørende folks privatliv. ${ }^{2}$ På samme måde som den norske stat anbefaler at man bruger ordet leder og ikke formand, ${ }^{3}$ har den bestemt at ligestilling er en vigtig politisk sag, og det forholder universiterne sig rimeligt loyalt til, selvom der selvfølgelig mukkes lidt i krogene. Det ville 
være nærmest utænkeligt at nogen officielt gav udtryk for at køn og ligestilling var en uvæsentlig problemstilling i akademia. Alligevel går tingene ikke så forfærdelig stærkt her heller. Hege Skjeie, medlem af gruppen bag den pågående norske magt- og demokratiudredning, har træffende karakteriseret den norske ligestillingssituation som 'en sump af velvilje'. ${ }^{4}$ Det tyder på at der er nogle underliggende prosesser som ikke rigtig blev analyseret midt $\mathrm{i}$ al den pragmatiske handlingsorientering.

\section{NY KUNDSKAB}

Hvis danskerne hænger efter i praksis, så må man til gengxld sige at de kommer tungt ind på banen når de nu præsenterer deres analyser af problemet. Mig bekendt er den danske forskningsrådssatsning Kønsbarrierer $i$ de hojere uddannelser og forskningen den største nogen sinde på dette felt i Nordisk sammenhæng. Projektet har givet os helt nye typer af viden, fra klasserumsobservationer af forskerkurser, analyser av universitetslæreres og universitetsfagenes kønskonstruktioner, til analyser af karrierespor og ansættelsesstatistikker over tid, og af hvordan forskningsbegreber og kønsforståelser slides af tidens tand. Hvis jeg skal fremhæve noget må det være den enorme styrke det er at projektet har indbefattet en så engageret og dygtig statistiker som Inge Henningensen. Men jeg synes samtlige rapporter er usædvanligt interessante og informative, og ikke mindst den helhed de tilsammen udgør og det historiske udviklingsperspektiv der anlægges gør projektet unikt også i nordisk sammenhæng. Hvad enten man har kørt store datasæt gennem computeren, sendt spørgskemaer ud, siddet som deltagende observatør i studiehverdagen, interviewet mennesker, eller analyseret politiske dokumenter eller massemedier, fremkommer den samme gestalt: mand $i$ centrum, kvinder $i$ periferien. Og mønsteret gentager sig på alle tidsnedslag og alle skalaniveauer og på en måde som bringer både kaosteoriens billeder af ordnet uorden og Yvonne Hirdmanns 'jernhairde genuslov' i erindring. Det er vigtig kundskab, og det er godt dokumenteret. Men så er jo bare spørsmålet om der ud af denne skattekiste springer nogle nye handlingsperspektiver, for det var jo den helt eksplicitte begrundelse i sin tid som forskningsrådene gav for at bevilge penge til projektet, og om det danske kønspolitiske klima - indenfor og udenfor akademia - er klar for dem? Hvis den norske ligestilling tenderer mod at stagnere i en sump af velvilje, kan man måske ængste sig for om den danske nu vil drukne i en sump af kundskab? Det vigtigste nu må være at sørge for at det ikke sker og jeg vil derfor her reflektere lidt over forholdet mellem analyse og forandring. Afsættet tages $\mathrm{i}$ tre forskellige typer nyttig indsigt læsningen gav mig: myteaflivning, procesforståelse og betydningen af kønnede koder og dybmetaforer.

\section{MYTEAFLIVNING}

Kønsbarriereprojektet har aflivet nogle populære forklaringer på, hvorfor det går så langsomt med at få rettet kønsskævheden i akademia op. Dette er virkelig nyttigt. Det giver mulighed for at undgå den tavshed og mistillid som ofte følger $i$ en samtale når påstand står mod påstand. Jeg kan nu slå venligt i bordet med dokumentation, indsamlet ved hjælp af genkendelige og alment accepterede forskningsmetoder. Jeg har skrevet alle de tilbageviste myter op på et stykke papir (med den vigtigste dokumentation og referencer til Inge Henningsen, Lis Højgaard og Hanne Nexø Jensens flotte analyser) og dette ark bærer jeg med mig overalt og tager det frem hver gang jeg møder påstandene om at:

- Det er jo bare et efterslab, problemet loser sig selv (forkert!)

- Alle universitetsstillinger besattes $i$ àben konkurrence (forkert!)

- Det er de bedste forskere som fär stillingerne (forkert!) 
- Køn som systemkrav vil bidrage til at sanke kvaliteten (forkert!)

- Kvinder søger ikke stillingerne fordi de ikke vil forske (forkert!)

- Der er ikke nok kvalificerede kvinder (forkert!)

- Kvinderne er jo ikke så dygtige som mandene (forkert!)

Når vi så er igennem listen vil jeg se forventningfuldt på min diskussionspartner og spørge hvad det mon så kan skyldes? Jeg behøver slet ikke påstå noget om lyssky korridorpolitik eller bruge vanskeligt teoretiske skyts. Jeg kan bare afvente at han, som den søgende forskersjæl han er, selv leder efter alternative forklaringer. Jeg glæder mig allerede.

\section{PROCESSER OVER TID, METAFORER SOM FANGER}

Måske kan jeg hjælpe ham på vej med de andre to typer af indsigt jeg har fra Kønsbarriereprojektet. Den ene er påvisningen af at kønsbarrieren er et procesfenomen: den skabes over tid og ved en rakke samvirkende forhold. Det er samspillet mellem de strukturelle forhold, den forskningspolitiske organisation, forskningsbegreberne, institutionskulturene, pædagogikken, de individuelle præferancer og reaktionsmåder, og alle de tolkningsrammer de repræsenterer, som tilsammen skaber det som i statistikken rejser sig som en kønsbarriere. Det er ikke den enkelte ting, isoleret set. Dette er ting vi nok har anet før, men som har været svært at dokumentere eller sandsynliggøre. Det er blevet nemmere nu, takket være Kirsten Reisby, Susanne V. Knudsen, Kirsten Gomard, Helene Sørensen, Anne-Mette Kruse, Charlotte Bloch og Cathrine Hasse.

Den anden indsigt er at disse processer henter sin kraft fra kulturelle koder og $d y b$ metaforer om køn som hele tiden indfanger vores forsøg på at tænke frit og nyt, ja, som er selve essensen af det kulturelle køn: Mænd er 'naturlige' hovedpersoner, kvinder er bipersoner. Mænd kan være individer og køn samtidigt; kvinder må vælge. Dorte Marie Søndergaard, Eva Bendix Petersen, Iris Rittenhofer, Birthe Klock Frederiksen og Palle Rasmussen er gode vejvisere i det komplicerede vejnet akademias diskurser om køn og kompetence danner. I Iris Rittenhofers optik: kategorien kvinde associeres til kategorien masse, mens kategorien mand associeres til en som adskiller sig fra mængden. Når denne dybmetafor kobles til akademias neutralitetsdiskurs om at vælge 'den bedste' blir excellence noget der egentlig bare kan bæres af en mand, eftersom 'den bedste' netop er en der adskiller sig fra massen. Dette er antageligvis en af grundene til at vi hele tiden ser nye differentieringer når de gamle er blevet for lidt elitære. I Norge, hvor professorkategorien næsten er ved at blive en massebetegnelse, har man nu lavet en særlig fin professorkategori for fagligt lederskab. Her er kvindeandelen igen nul. Det samme gælder ledelsen for de nyoprettede Centres of Excellence. 5 På samme måde som det stort set er mænd som hives op fra massen gennem individuelle lønforhandlinger, i takt med at man samtidig arbejder for lønudjævning mellem kønnene. De ligestillende og de forskelssættende processer ser ud til at gå hånd $\mathrm{i}$ hånd. Hver gang kvinderne erobrer en kategori bliver den en massekategori som tendensielt ødelægger det begreb om excellence som er akademias fundament. Da må nogle mænd legemliggøre det igen.

Jeg er ikke i tvivl om at kønsmetaforene og deres sammenstød med akademias neutralitetsdiskurs udgør noget af kønsbarrierens mest genstridige stof. Problemet er bare at min samtalepartner er faldet af for længst. Samtalen begyndte ellers så godt, nu forstår han ikke en lyd af, hvad jeg siger. Det hjælper heller ikke at jeg læser op fra Henningens og Højgaards konklusion som er lysende klar og præcis for mig i sin kobling af proces- og diskursperspektiverne:

I dag er problemet ikke så meget en åbenbar diskrimination, som et resultat af de igangvæ- 
rende subtile mekanismer, utilsigtede konsekvenser og den kønssymbolske ordens stædige sindrighed. 'Lxkagerne' er et resultat af interaktionen mellem de individuelt medierede forhandlinger af kulturelle forskrifter for kønnet subjektivitet og identitet, de organisatoriske forståelser de producerer, som er indvavet i de specifikke institutkulturer, de epistemiske kulturers fagtraditioner, den systemiske logik og det politiske rationale, der lever i forsknings- og uddannelsessystemet.

(Rapport 9, s. 25)

Hvis min samtalepartner definerer sig som kritisk humanist eller samfundsforsker, som hermeneutiker, kulturanalytiker, diskursanalytiker og dekonstruktionist er der tale om en akut tunghørhed eller 'vidensvagring’ som Dorte Marie Søndergaard kaldte det i sit indlæg på Christiansborg da projektet blev fremlagt i oktober 2002. I en hver anden sammenhæng ville han mene at kundskab er magt. Men det gælder ikke for køn, og ikke for ham selv. Hvis han (eller hun) kommer fra naturvidenskab tror de sandsynligvis jeg snakker sort, for der er de vant til de at forstå sproget som et redskab til at beskrive virkeligheden og ikke som noget der styrer forestillingerne om virkeligheden. Hvis forudsætningen for at fă ligestillingsbudskabet igennem er kendskab til de sidste 50 års udvikling $\mathrm{i}$ humanistisk videnskabsteori begynder det at se mørkt ud.

Problemet jeg vil frem til har to sider. Den ene er, hvordan vi formidler de komplicerede pointer om procesfænomener og diskursiv konstituering af køn og kompetence til andre end de allerede indforståede? Og det er vi nødt til hvis vi vil have politiske alliancer, og undgå at snakke ud i et tomrum. I en relativ ny rapport om ligestilling i forskningssektoren fra Norges Forskningsråd 6 er man inde på samme problem: hvordan kan ligestillingsarbejdet og kønsbarrierer gives mening $i$ og for Akademia? Den anden side af problemet er at det heller ikke er nogen let opgave at udlede klare politiske tiltag når kønsbarrieren viser sig at bestå af så subtile, komplekse og akkumulative processer. Hvad sætter gang i forandringsprocesser i dette komplekse felt?

\section{'TEORIPOLITISK KORREKTHED' OG FORANDRING}

Da de danske kvindeforskere for 25 år siden afviste den norske institutionaliseringsstrategi blev der, sådan som jeg husker det, blandt andet argumenteret ud fra en teoretisk analyse af at borgerligt-patriarkalske institutioner som universiteterne uvægerligt ville kooptere og ufarliggøre kvinders utopier. Den norske og den danske udvikling siden da giver dem både ret og uret. Institutionaliseringsstrategien har ikke revolutioneret universitetet og forskningen i Norge, men situationen for både ligestilling og kønsforskning er klart bedre end i Danmark. Set i historiens bakspejl vil jeg altså plædere for at den norske strategi førte til mere forandring. Den danske strategi kan selvfølgelig forstås som en respons på den situation at der faktisk ingen stillinger var at besætte, ${ }^{7}$ men jeg mener at 'teoripolitisk korrekthed' også spillede en rolle. Med teoripolitisk korrekthed mener jeg at politiske handlingstiltag vurderes ud fra om de kan legitimeres på grundlag af den teori som på et givet tidspunkt regnes for 'den rette'. I den senere tid har vi faktisk set nye krav om teoripolitisk korrekthed gøre sig gældende i Norge, måske som en reaktion på den tidligere handlingsiver. I et afsluttende kapittel om ligestillingens kundskabsgrundlag i den omtalte NFR-rapport advares der mod tiltag som enten kan lede til forkerte forståelser af hvad køn er, eller som:

...ikke medfører varige endringer av strukturell eller politisk art. Å øremerke stillinger til kvinner er egnet til å endre statistiske forhold - ikke arbeidsmiljøet, organisasjonskulturen eller andre faktorer som muligvis holder kvinner nede i eller utenfor et spesifikt stillingshieraki (p.167) 8 
Den samme purisme var på færde da en gruppe af stipendiater sidste år indklagede Norge for EFTA-domstolen fordi de mente brugen af øremærkede stillinger til kvinder var kønsdiskriminering. Dette var unge forskere af begge køn, med faglig forankring i moderne socialkonstruktionistisk teori, der ikke mener at det rokker ordentlig ved diskurserne bare at få et par kvinder mere ind. Øremærkning var ikke radikalt nok. Universitetet burde i stedet sigte mod at fjerne alle typer af diskriminering $\mathrm{i}$ alle ansættelsesprocesser og da ville det jo være ulogisk samtidigt at diskriminere kvinder ind. Spørsmålet er om dette ikke er fejlplaceret brug af logik. I Norge har den ført til at man nu har mistet retten til øremærkning af stillinger - uden at kreative forslag til hvordan man fjerner 'al diskriminering', hidtil har ladet sig høre fra den renfærdige flok. Sådan kan det gå når det bedste bliver det godes fjende.

Der ligger en problematisk forståelse af, hvad forandring er i en sådan teoripolitisk korrekthed. Det antages at forandring sker som en logisk, fremadskridende proces, hvor der er nøje overensstemmelse mellem teorigrundlag og praktisk effekt. En forstilling om at tingene enten går fremover eller bagover og at vi på forhånd kan analysere os frem til hvad der er tilfældet. I min forståelse er det ikke sådan forandring sker. Jeg tror tværtimod at social forandring kan minde til forveksling om den slags komplekse processer over tid som også kan vedligeholde sociale strukturer som f.eks kønsbarrierer. Et par kvinder mere på et institut ændrer næppe kulturen med ét slag, men det kan faktisk ikke forudsiges, hvad der vil ske. Det kommer an på den konkrete situation, hvordan de ansatte kvinder går ind $\mathrm{i}$ den, hvem der er der $\mathrm{i}$ forvejen, hvad der sker i samfundet i øvrigt i samme periode osv. osv. Der kan tænkes både progressive og regressive effekter, afhængigt af den konkrete situation, og de udelukker ikke engang hinanden. F.eks. vil et ligestillingstiltag, som implicerer en essentialistisk kønsforståelse måske være nemmere at få igennem i et miljø, hvor man netop har en sådan forståelse - samtidig med at effekten af tiltaget udmærket kan svække denne forståelse over tid alligevel. Videnskabelig analyse og politisk handling er forskellige sprogspil. Med dette mener jeg ikke at man skal være blind for faktiske og utilsigtede konsekvenser af de tiltag man sætter iværk, men forestillingen om at de er entydige, logiske eller forudsigelige tror jeg ikke på. Hvis stipendiaternes argument havde været at øremærkningmidlet skaber så megen modstand mod ligestillingsarbejdet på universitetet at det der vindes på gyngerne kan tabes igen på karusellerne, synes jeg de havde haft en bedre pointe (og den havde næppe ført til anmeldelse af den norske stat for kønsdiskriminering).

\section{FORANDRINGSPROCESSER INDENFOR, UDENFOR, UDENOM OG IND I DISKURSERNE}

Jeg håber at det danske Kønsbarriereprojekt vil klare at bevare sin flotte bredspektrede tilgang til problemerne også når handlingskonsekvenserne skal diskuteres og den opsummerende rapport fra hele projektet tyder da også i denne retning. Med det kolde danske kønspolitiske klima drejer handlingstiltag sig måske i endnu højere grad end i Norge om at skabe forståelse for at der overhovedet foreligger et problem, altså om at indlede samtaler om ligestilling på mange niveauer. 'Samtaler' er ingen garanti for forandring, men de kan være en del af den. Afhængig af tid, sted og modtagere må vi være parate til, nogen gange, at argumentere på diskursens egne præmisser, andre gange at imødegå dem, afsløre dem, eller omgå dem. Hvad der er tilrådeligt $\mathrm{i}$ en given situation handler om en vurdering af styrke, alliancer og faktiske konsekvenser. Der findes ikke nogen uangribelige og heldækkende politiske tiltag sådan som den teoripolitiske korrekthed synes at forudsætte, det handler om hele 
tiden at puffe til stivnede systemer og skeptiske forvaltere på opfindsomme måder.

At argumentere indenfor diskursen kan være en god åbning overfor alle i akademia som ikke allerede har købt budskabet, hvad enten de er forskere, lærere eller studenter. Her tager vi meritokratiet for alvor, og det er i grunden ikke så svært, for kvindelige lærere og forskere bruger det jo selv hver dag. Hvordan skulle vi ellers kunne vejlede, eksaminere, bedømme, ansætte? Vi kan mødes i et fæelles behov for regler og normer og en falles forpligtelse til at bruge dem på en åben og selvkritisk måde. Når vi er i denne modus kan vi bruge løs af den myteaflivende dokumentation, og vi kan som Henningsen og Højgaard foreslår, prøve at udvide begrebet om faglig kvalitet lidt, gøre det lidt mindre konventionelt og skråsikkert. Kræve brede stillingsopslag, eksterne komiteer med integritet, undgå personlige udnævnelser. Vi kan også godt tillade os at arbejde indenfor 'eksternaliseringsdiskursen', dvs tage udgangspunkt i det forhold at kønsbarrieren også reproduceres i et samspil med diskurser og prakisser som til dels ligger udenfor akademia. Her tager vi de individuelle medieringer af kønsdiskurserne for alvor. De forskere i kønsbarriereprojektet som har deltaget i studenternes hverdag har observeret forskelle i kommunikationsstrategier, karrierestrategier, selvfremstilling, adfærd, motivation, præferencer, kort sagt, diskursens tilstedeværelse $\mathrm{i}$ individernes hoveder og kroppe som 'babitus' eller 'sprezzatura'. På dette niveau kan virkemidlerne være at støtte, rådgive, bygge netværk, lave mentorprojekter, lave pædagogisk udviklingsarbejde, argumentere for flere ressourcer til kvinder osv. Fagene, fagkulturerne og de kønnede koder som møder de individuelt medierede køn er forskellige, og det må der også tages højde for her.

Virkemidler som øremærkning, kønskvotering, systemændringer og måltal argumenterer udenfor diskursen ved at imødegå den. Man påpeger at meritokratiet er en il- lusion, og kræver retfærdighed og magtbalance: når mænd tildeler hinanden stillinger er det ret og rimeligt at kvinder får kompensation. Denne samtalestrategi egner sig ofte godt i forhold til politikere og administratorer. I Norge har det fungeret ganske godt i nogle år. Nu må vi til at finde på noget nyt - men øremærkningsperioden har samtidig bidraget til at der nu er flere kvinder til at gøre det. ${ }^{9}$

En tredje mulighed er at prøve at omgå diskursen, dvs finde virkemidler som ikke vækker de slumrende kønsmetaforer når meritokratiet praktiseres. Kan man f.eks finde metoder hvor vi lurer koblingen af 'den bedste' = 'mand'? Hvad nu hvis man slog to stillinger op samtidig - så var det måske mindre provokerende at den ene var en kvinde? Eller kunne man udnytter det at kvinder opfattes som massebetegnelse ved at indføre gruppearbejde som pædagogisk metode? Måske er det smartere at arbejde for øremærkede stillinger inden for områder, hvor der er mange kvalificerede kvinder end at øremærke stillingerne efter køn? På den måde ville man ikke principielt udelukke mænd fra at være ansøgeree (det var det EU-domstolen ikke kunne lide), men øge muligheden for at der ville komme mange gode kvindelige ansøgere. Denne samtalestrategi kan tænkes at være hensigtsmæssig i universitetspolitiske organer.

Endelig er det en mulighed at gå ind $i$ og 'afklede' diskurserne, sådan som Dorte Marie Søndergaard anbefalede det i sit afslutningsforedrag. Der er ingen tvivl om at dette kan have en stærkt provokerende virkning og i heldige tilfælde rive skællene fra øjnene. Men den indbyggede provokation kan også gøre den vanskelig som kommunikationsstrategi: Den objektiverer modtageren på en måde som samtidig ekskluderer ham som samtalepartner, eller som gør samtalen terapeutisk. Ligesom spisevægrere er det antageligvis de færreste vidensvægrere som bryder sig om det, med mindre de selv har søgt hjælp. Afsløringstrategien virker derfor nok bedst som 
baggrundstæppe for vores egen forståelse, og som orienteringsredskab for unge kvinder som bliver forvirrede over de modssætningsfyldte budskaber de modtager i Akademia. Det vil dog nok være hensigtsmæssigt at kombinere denne dose diskursanalyse med en tilsvarende dose konkret opbakning og gode overlevelsesråd.

\section{NOTER}

1. I Norge udgjorde kvinder i $199924 \%$ af de fastansatte på universiteter og videnskabelige højskoler, $12 \%$ professorer, og $42 \%$ stipendiater (NFR: Kvinder i forskning, 2002). De tilsvarende danske tal er $18 \%, 8 \%$ og $43 \%$. I 2001 er de norske tal vokset med et procentpoint, til 25\%, 13\% og 43\%. Det har været en meget stærkere vækst i kvindeandelen i faste stillinger i Norge end i Danmark de sidste 20 år. Det kan der være mange - og samvirkende - forklaringer på. En er at der har været flere ledige stillinger på universiteterne i Norge i løbet af perioden. En anden er den mere aktive ligestillingspolitik. Men, som Inge Henningensen sagde det ved et møde på Universitetet i Oslo 14.1.03, kan det også skyldes at Norge bare har været forsinket med hensyn til at nå glasloftet på 20-30\% kvinder. Indtil det modsatte er bevist sætter jeg min lid til en kombination af de to første forklaringer...

2. For en uddybning af denne forskel i norsk og dansk kultur, se min artikel 'Feminismer og pornografi' i Nytt norsk tidsskrift 2/1998

3. Norsk sprogråd har udgivet en brochure som hedder "Kjønn, språk, likestilling". Der står der bl.a.: "Vi tilrår kjønnsnøytrale betegnelser for tillitsverv o.l.: leder (formann), nestleder (nestformann, varaformann, viseformann), ordenselev (ordensmann), tillitsvalgt(tillitsmann)". Efter 20 år i Norge gibber det faktisk i mig når jeg ser at kønsbarriereprojektets leder Anette Borchhorst underskriver sig som formand. Det havde ikke bare været politisk ukorrekt i Norge, det havde været imod de statslige direktiver.

4. På norsk: 'En myr av velvilje'. Interview i Aftenposten, februar 2002. Hege Skjeie og Mari Teigen har netop udgivet en ny bog fra den norske magtog demokratiudredning, hvor de uddyber denne karakteristik (Skjeie, H. og M.Teigen. 2003. Mannsdominans og likestillingspolitikk. Oslo: Gyldendal Akademisk).
5. På norsk kaldet SFF: Sentre for fremragende forskning. 13 sådanne centre med store bevillinger blev oprettet i 2002. Alle er ledet af mænd.

6. Kvinner i forskning - fra kvotering til integrering. Norges Forskningsråd, maj 2002.

7. Tak til Fride Eeg-Henriksen på NIKK for denne pointe.

8. Denne holdning formidles i det afsluttende kapitel: 'Teoretisk bakgrunn: kunnskapsgrunnlagets forutsetninger og dimensioner'. I den øvrige rapport diskuteres der mange konkrete tiltag for at fremme ligestilling både via integrering og som særskilte tiltag. Rapporten er med andre ord nok så inkonsekvent.

9. I den periode øremærkning af stillinger til kvinder har været tilladt er der på de fire norske universiteter blevet besat ca. 30 øremærkede professorater og ca. 80 øremærkede postdoc-stillinger (der findes ingen centrale tal fordi der i tillæg til de stillinger som blev bevilget over statsbudgettet også er blevet bevilget stillinger lokalt - 30/80 er derfor et løseligt anslag). Selvom øremærkningsmidlet ikke i sig selv garanterer at de ansatte kvinder er ligestillingsentusiaster, er det næppe sandsynligt at ca. 110 ekstra kvinder ligefrem vil bidrage til at forstærke patriarkalske strukturer i Akademia.

\section{SUMMARY}

The impressive research project Gender Barriers in Higher Education and Research (The Danish Research Councils, 1998-2002) has persuasively demonstrated that the Danish university system systematically places men in the centre and women in the margins at all levels within the fields of education and research. The manifold reports from the project give important insights into the complex mechanisms of gender discrimination in academia: the prevalence of false myths about women in research, the profound significance of gendered codes and metaphors, and the cumulative effects of discriminatory practices on many different levels. The main question raised in this essay is how such insights could be made into a practice of change. The complexity of the phenomenon itself and of the analysis of it makes it difficult to translate 
into political action, and may also represent a binder for communicating the problems to others than those who are already familiar with them.

It is argued that a multiple approach should be applied, and that demands on 'theory-political correctness' should not be used to limit possible positive political interventions. It is fully viable at one and the same time to argue within, without, round, and about the discourses of gender and meritocracy in academia. Which communicative strategy will be most effective can only be decided in relation to specific contexts.

Harriet Bjerrum Nielsen, professor og leder af Senter for kvinne- og kjønnsforkning ved Universitetet i Oslo 